\title{
Manganese the protector
}

\author{
John Emsley looks at an element that is vital to life.
}

M anganese is an essential element for all species. It has a key role in protecting cells against the superoxide free radical $\mathrm{O}_{2}^{-}$, and does this as the enzyme manganese superoxide dismutase (Mn-SOD) which converts $\mathrm{O}_{2}^{-}$to $\mathrm{H}_{2} \mathrm{O}_{2}$. Manganese is also needed for other enzymes, and is involved in glucose metabolism, the utilization of vitamin B1, and the operation of RNA.

It was only realized in the 1950s that humans need manganese, partly because our requirement is so small: the average person contains only about $12 \mathrm{mg}$. The daily intake averages $4 \mathrm{mg}$, which is more than enough. Many foods provide this element, especially cereals and nuts. Beetroot has one of the highest levels, as has the French delicacy, snails. Too much manganese in the form of dust or fumes, however, can send you crazy, and miners of manganese minerals used to suffer the symptoms of 'manganese madness' with involuntary laughing or crying, aggression, delusions and hallucinations.

The power of Mn-SOD in protecting living cells was demonstrated in the 1950s by the microbe Deinococcus radiodurans. This organism is able to survive in meat subjected to intense radiation by accumulating manganese in preference to iron, and using it to destroy the devastating number of oxygen free radicals that the radiation produces. In so doing, it enables the DNA repair mechanism of cells to continue functioning and not be completely overwhelmed.

Manganese was known long before it was isolated as an element. It occurs as the black ore pyrolusite (manganese dioxide), which was used by the cave artists of the Lascaux region of France more than 30,000 years ago. The Roman author Pliny the Elder, who perished when Pompeii was destroyed in $79 \mathrm{AD}$, wrote of a black powder that glass-makers used to make their products crystal clear - this was almost

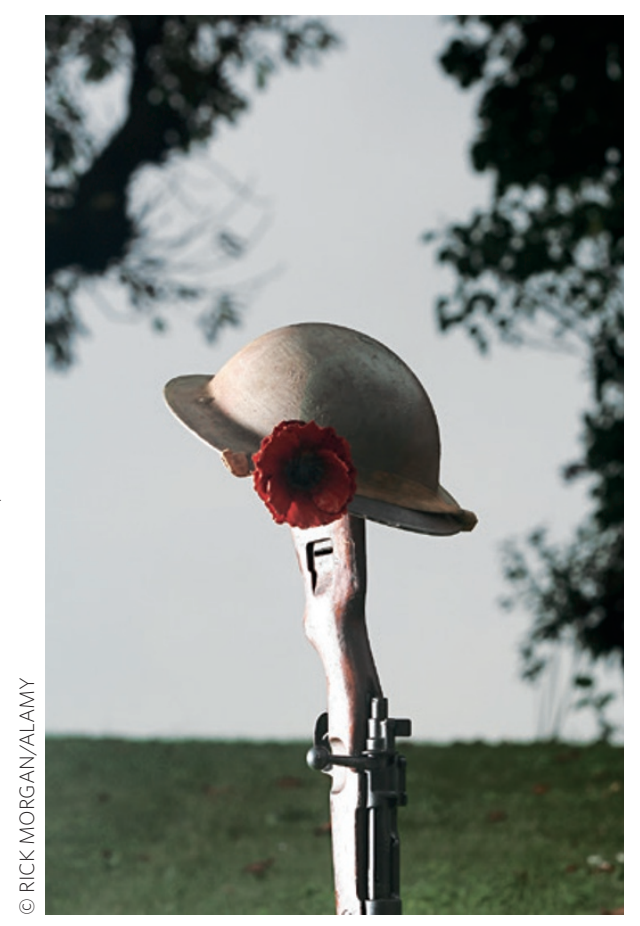

certainly pyrolusite, and it was also used as a black pigment by potters.

Manganese ores have also provided evidence of changes in planetary diversity over the millennia. The lack of manganese in sedimentary rocks in the period between 400 and 1,800 million years ago indicated a time when the oceans had low oxygen levels ${ }^{1}$.

Pyrolusite is the most common manganese ore, of which around 25 million tonnes are mined every year. If the land-based deposits were ever to be exhausted then we would have to exploit the manganese nodules on the ocean floor. There are an estimated trillion tonnes $\left(10^{12}\right)$ of these scattered over large areas, with the North East Pacific being particularly rich in them. In 1876 the sailing ship Challenger was sent to explore the deep oceans and it returned with curious, cone-shaped lumps that had been dredged up from the ocean floor. They turned out to be mainly manganese and seem to have formed around sharks' teeth, which are one of the few parts of living things capable of surviving at the bottom of the ocean.

Life has been intimately linked to manganese, and in parts of the ocean devoid of iron the success of marine diatoms relies on this element ${ }^{2}$. This microbial attraction to manganese might one day be the basis of an alternative source of the metal by using microbes to extract manganese from lowgrade ores, as is currently done for copper and gold ${ }^{3}$.

Manganese metal is not used as such because it is too brittle, and $95 \%$ of mined ore goes into alloys - mainly steel, to which around $1 \%$ is added to improve its strength, working properties and wear resistance. The alloy known as 'manganese steel' contains around $13 \%$ manganese, and a patent for this was granted in 1883 to a 24 -year-old metallurgist, Robert Hadfield of Sheffield. This metal is extremely strong and is used for railway tracks, earth-moving machinery, safes, army helmets, rifle barrels and prison bars, and is still referred to as Hadfield steel.

Manganese compounds also find use, for example manganese(Iv) dioxide $\left(\mathrm{MnO}_{2}\right)$ is added to rubber and is used as an industrial catalyst, and manganese(II) oxide $(\mathrm{MnO})$, goes into fertilizers applied to manganese-deficient soils. Potassium permanganate $\left(\mathrm{KMnO}_{4}\right)$ - with the $\mathrm{Mn}$ (VII) oxidation state - is used to remove organic impurities from waste gases and effluent water. The characteristic purple of potassium permanganate is thus only a minor, albeit colourful, aspect of an element that plays a key part in our lives and that of planet Earth.

JOHN EMSLEY is a science writer and author of Nature's Building Blocks and other books.

e-mail: JohnEmsley38@aol.com

\section{References}

1. Maynard, J. B. Econ. Geol. 105, 535-552 (2010).

2. Wolfe-Simon, F. et al. Plant Physiol. 142, 1701-1709 (2006).

3. Das, A. P. et al. Bioresource Technol. 102, 7381-7387 (2011).

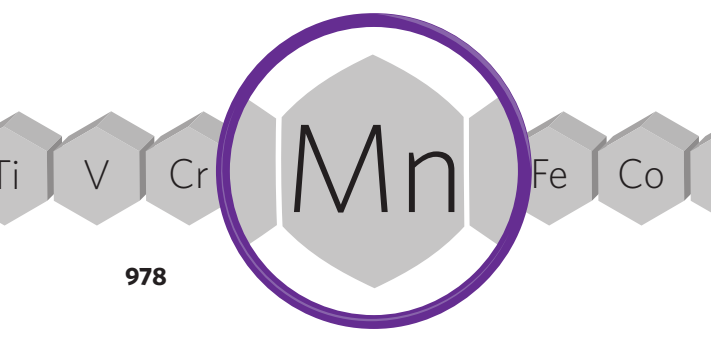


in your element

\section{ADDENDUM}

\section{In Your Element: Manganese the protector}

John Emsley

Nature Chemistry 5, 978 (2013); published online 24 October 2013; corrected after print 3 October 2014.

In the version of this In Your Element article previously published, it should have stated that some passages in this essay are based on the manganese chapter in the author's book, Nature's Building Blocks. 